\title{
Role of Phytoestrogens in Cancer Therapy
}

Authors

Affiliations
Mandeep K. Virk-Baker ${ }^{1}$, Tim R. Nagy ${ }^{1}$, Stephen Barnes ${ }^{2,3}$

${ }^{1}$ Department of Nutrition Sciences, University of Alabama at Birmingham, Birmingham, AL, USA

${ }^{2}$ Department of Pharmacology \& Toxicology, University of Alabama at Birmingham, Birmingham, AL, USA

${ }^{3}$ Center for Nutrient-Gene Interaction, University of Alabama at Birmingham, Birmingham, AL, USA

\section{Key words \\ - phytoestrogens \\ - cancer therapy \\ - cell cycle regulation \\ - inflammation \\ - angiogenesis \\ - metastasis}

received Dec. 31, 2009 revised May 20, 2010 accepted June 2, 2010

Bibliography

Dol http://dx.doi.org/ 10.1055/s-0030-1250074

Published online July 1, 2010 Planta Med 2010; 76:

1132-1142 (c) Georg Thieme Verlag KG Stuttgart · New York . ISSN 0032-0943

\section{Correspondence}

Stephen Barnes, PhD

Department of Pharmacology

and Toxicology

452 McCallum Research

Building

University of Alabama

at Birmingham

1918 University Boulevard

Birmingham, AL 35294

USA

Phone: + 12059347117

Fax: + 12059346044

Sbarnes@uab.edu

\section{Abstract \\ $\nabla$}

Cancer is a leading cause of death worldwide, and the numbers of new cancer cases are expected to continue to rise. The main goals of cancer therapy include removing the primary tumor, preventing the spread of distant metastases, and improving survival and quality of life for the patients. To attain these goals of cancer therapy, the combination of different chemotherapeutics, as opposed to the conventional single-agent treatment, is an emerging area of research. Given the potential risks of drug toxicity in such treatment, the focus is to have a second compound that increases the anticancer potential of the primary agent but which reduces toxicity. There is an ever growing interest in treatment with natural compounds, such as plant phytoestrogens, as an adjuvant cancer therapy along with conventional cancer therapy. The question remains whether or not adding these compounds to the cancer therapy regimen as a second agent would be beneficial, and if they are safe to be used among cancer patients. The current literature suggests that phytoestrogen treatment is capable of inducing G2/M cell cycle arrest in a number of cancer cell lines, as well as upregulating cell cycle inhibitory molecules. Phytoestrogen therapy has been shown to inhibit inflammation, angiogenesis and metastases in various in vivo tumor models, and pronounced bene-

\section{Introduction}

In many patients with breast cancer and prostate cancer, the tumors are hormonally dependent [ 1 , 2]. This has led to anticancer therapeutic approaches that involve antagonists to estrogens (the use of tamoxifen in breast cancer) [3], or to inhibitors of estrogen/androgen synthesis (aromatase inhibitors in breast cancer [4] and diethylstilbestrol and finasteride in prostate cancer [5]. fits have been observed when combined with radiation therapy. The lack of side effects from phase I and II clinical trials of phytoestrogens in cancer therapy points towards their safety, but to further understand their added benefit clinical studies with large sample sizes are required. We have reviewed the recent research studies in these areas in an attempt to find evidence for their role in cancer therapy as well as safety.

\section{Abbreviations \\ $\nabla$}

CAM: chicken egg chorioallantoic membrane

COX-2: cyclooxygenase-2

Cdk: $\quad$ cyclin-dependent kinase

ELN: enterolactone

HMR: hydroxymatairesinol

NSAID: nonsteroidal anti-inflammatory drugs

NFkB: $\quad$ nuclear factor kappa B

OPN: osteopontin

PSA: $\quad$ prostate specific antigen

SOD1: $\quad$ superoxide dismutase-1

TPA: 12-O-tetradecanoylphorbol 13-acetate

VEGF: vascular growth factor 
estimated as being a 1-2\% increase in risk per year of use of estrogen therapy [8]. This has promoted the search for selective estrogen receptor modulators (SERMs) - compounds that provide benefit by promoting good bone health, but which do not act as estrogens on estrogen-sensitive tumors [9]. Raloxifene is an example of an SERM that was generated by chemical synthesis [10]. However, investigators have also pursued the concept that plant estrogens (phytoestrogens) that are part of the diet may have a role as natural SERMs $[10,11]$.

Besides their property of being estrogen receptor agonists, phytoestrogens have several other biological mechanisms of action. They include being protein tyrosine kinase inhibitors (e.g., the epidermal growth factor receptor) [12], antioxidants [13], inhibitors of tumor necrosis factor alpha [14], inhibitors of $3 \beta$ - and $17 \beta$-hydroxysteroid dehydrogenase activities $[15,16]$ and inhibitors of aromatase mRNA expression and activity [16], and agonists of the peroxisome proliferator activated-receptor alpha and gamma (PPAR) $[17,18]$. These other properties would be expected to differentiate phytoestrogens from physiological estrogens. Indeed, they have been reported to inhibit cell cycle events and prevent cancer in different preclinical models. In addition, epidemiological data have revealed that populations with a high intake of phytoestrogens in the diet have a very much lower incidence of breast and prostate cancer $[19,20]$. Since they can be tolerated at oral doses 16 times the maximum intake from the diet $[21,22]$, clinical investigations are underway to evaluate the effectiveness of phytoestrogens in the treatment of breast and prostate cancers. The present review will focus on roles of phytoestrogens in cell cycle regulation, inflammation, metastasis, and survival as they relate to the ongoing clinical trials. The literature search was performed with the PubMed search engine using the following criteria: manuscript publication years 20022009, and combinations of search terms: phytoestrogens, soy isoflavones, cancer, mechanism of action in cultured cell lines, various animal models, cancer therapy, survivorship and clinical experiments. If the manuscripts were not immediately available, reprints were requested from the corresponding authors. The principal exclusion criterion was for those manuscripts that added little or no new data to the existing information. In such cases, the original manuscripts were used for this study - this expanded our search time span beyond the initial 7-8 years guideline. The current ongoing trials on phytoestrogens were searched from the National Institutes of Health website to attain the most current information on such studies.

\section{Chemistry and Dietary Forms of Phytoestrogens}

Phytoestrogens are members of the polyphenols that are widely distributed throughout the plant kingdom. They are a subclass of the polyphenols that have structural similarity to the endogenous hormone $17 \beta$-estradiol, and bind to estrogen receptors. They may be broadly classified into four classes - isoflavones, lignans, coumestans and resorcyclic acid lactones or myco-estrogens. As their name suggests, the latter are a class of phytoestrogens that are produced by mold found on cereal crops. This review will address isoflavones ( $\bullet$ Fig. $\mathbf{1}$ ) and lignans ( $\bullet$ Fig. 2 ), as most research is focused on these two classes and very little is known about the other two classes. The main dietary sources of isoflavones include legumes such as soybean, kala channa, mung bean (green lentil), red lentils and red clover. Daidzein and genistein are the two major isoflavones present in soy. Lignans are
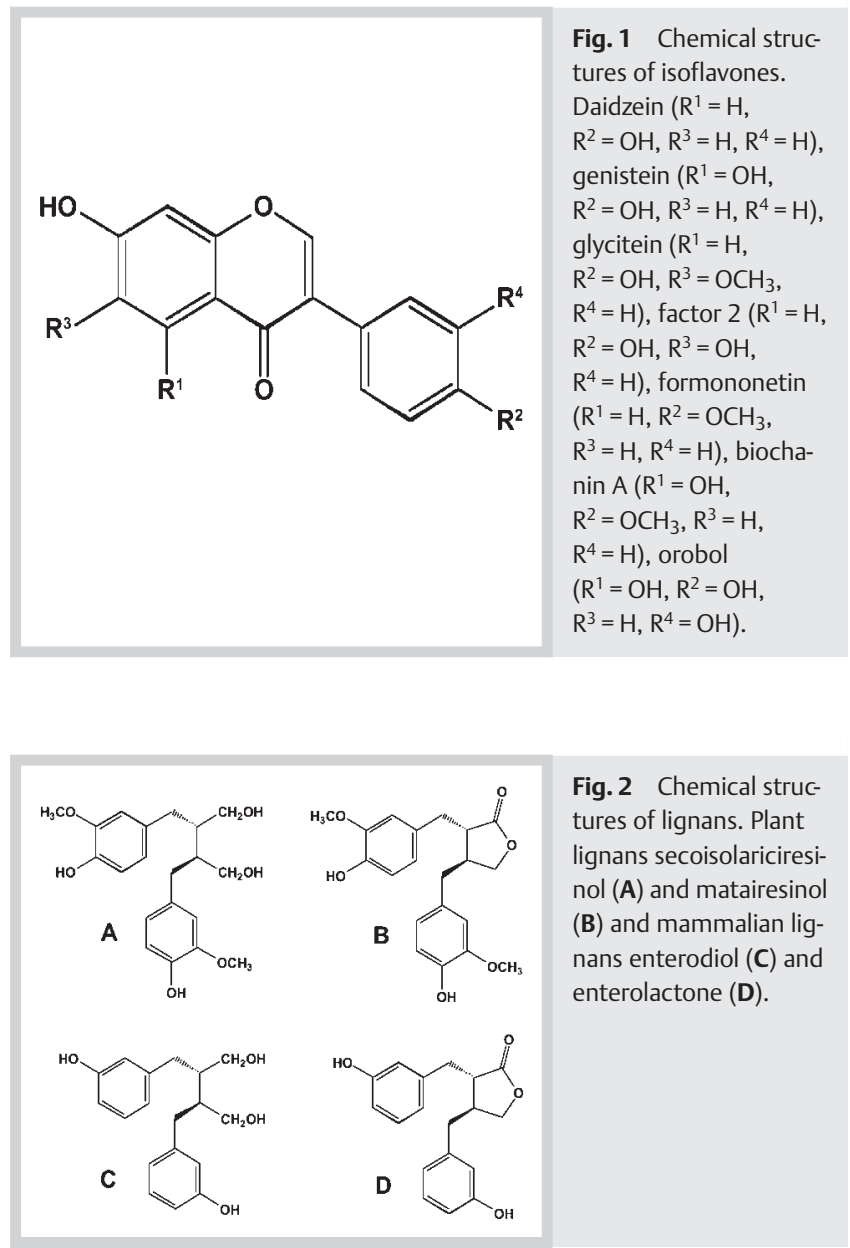

present mainly in flaxseed, seaweed, whole grains, legumes, oil seeds, fruits and vegetables. The two main lignans in food include secoisolariciresinol diglucoside and matairesinol, which are also the precursors of the mammalian lignans enterodiol and enterolactone. The phytoestrogen content of grain/cereal crops may be affected by genetic, environmental factors, as well as quantification methods used $[23,24]$. Intestinal bacteria play an essential role in the absorption and metabolism of both isoflavones and lignans. The detailed background on absorption and metabolism of different isoflavones and lignans is beyond the scope of this review - see [25-27]. For a detailed list of the isoflavone content of food items, please see the United States Department of Agriculture online database [28].

\section{Doses and Metabolism of Phytoestrogens \\ $\nabla$}

In evaluating the potential uses(s) of phytoestrogens, careful consideration should be given to the doses or concentrations used in preclinical experiments (cultured cell lines and animal models) and in clinical trials. When isoflavones are administered orally, intestinal cells are exposed to high phytoestrogen concentrations $(20-100 \mu \mathrm{M})$. Although the isoflavones are well absorbed in the small intestine [29], they are re-excreted into bile and hence the intestine as $\beta$-glucuronides. These are not well absorbed from the intestine until bacterial $\beta$-glucuronidases hydrolyze them in the large bowel. Cell culture experiments using intestinal cancer cells at high phytoestrogen concentrations are therefore relevant to in 
vivo situations. In contrast, cancer cells in organs at peripheral sites are exposed to phytoestrogen concentrations that are less than $1 \mu \mathrm{M}$, most of which are inactive $\beta$-glucuronide conjugates. When phytoestrogens are administered intravenously or intraperitoneally, the unconjugated (active) phytoestrogens can persist for longer periods of time and at higher concentrations. Phytoestrogen concentrations are nonetheless high $(1-50 \mu \mathrm{M}$ depending on dose) in two other non-gastrointestinal body fluids, in the urine [30] and prostatic fluid [31]. Since rodents have a high rate of metabolism, typically tenfold higher oral doses are required to achieve plasma phytoestrogen concentrations comparable to those in humans. Therefore, a daily dose of 50$100 \mathrm{mg}$ isoflavones $(0.7-1.4 \mathrm{mg} / \mathrm{kg}$ body weight) in humans would be equivalent to a daily dose of $7-14 \mathrm{mg} / \mathrm{kg}$ body weight in rodent models. Also note that giving a rat $1 \mathrm{mg}$ of genistein per day is equivalent to $\sim 4 \mathrm{mg} / \mathrm{kg}$ body weight (assuming a mean body weight of $250 \mathrm{~g}$ ). In the mouse a $1 \mathrm{mg}$ dose of genistein is equivalent to $25-50 \mathrm{mg} / \mathrm{kg}$ body weight (for mouse body weights of $20-40 \mathrm{~g})$.

\section{Effects of Phytoestrogens on the Cell Cycle}

$\nabla$

The cell cycle consists of four phases - G1, S, G2 and M. The progression through each phase is both ordered and controlled by various regulatory signaling molecules, and disruption in the regulation can result in neoplastic growth or cancer [32]. There are specific complexes for each phase and formation of cyclins and cyclin-dependent kinase (cdk) complexes and their degradation is essential for cell cycle progression. A number of studies have described an important role of phytoestrogens in regulating the cell cycle ( $\odot$ Table 1$)$. In a highly metastatic bladder cancer cell line (253J B-V), genistein has been shown to inhibit cell growth by inducing cell cycle arrest at the G2/M transition, and significantly reduced the expression of cell cycle regulators cyclin B1 and Cdk-1 [33]. The similar effect of genistein on G2/M arrest was observed in the cervical cancer cell line ME180 that contains integrated HPV-16 and HPV-18 [34]. In prostate cancer PC-3 cells, treatment with genistein, radiation, or as a combined treatment showed G2/M phase cell cycle arrest, and increased apoptosis in the combined treatment [35]. To understand the influence of the combined treatment on cell cycle progression, Western blot analysis of cell cycle regulatory molecule expression revealed a significant downregulation of cyclin B1 and upregulation of inhibitory molecule P2 $1^{\mathrm{WAF} 1}$ for genistein and the combined treatment. The monotherapy with either radiation or genistein increased the P21 WAF1 expression. However, radiation compared to all other treatments significantly increased cyclin B1 protein, suggesting that the combination treatment is needed to achieve optimum benefit than either treatment alone [12]. Soy isoflavones have growth inhibitory effects on breast, prostate, hepatic, pancreatic, cervical, and renal cell lines. Genistein $(100 \mu \mathrm{g} / \mathrm{mL} ; 370 \mu \mathrm{M})$ caused dose- and time-dependent inhibition of (SMRT R-1, R-2, R-3 and R-4) renal carcinoma cell lines [36]. Highly metastatic bladder cancer cells (253J B-V) treated with a range of various isoflavone concentrations $(10-50 \mu \mathrm{M})$ for 48 hours showed growth inhibition effects, with genistein being the most effective even at the lowest dose of $10 \mu \mathrm{M}$ [33].

\section{Role of Phytoestrogens in Inflammation}

Inflammation is a biological response of vascular tissue and is important for immune response and wound healing [37]. However, in cancer, inflammation can create a microenvironment around the tumor, resulting in the attraction of chemokines, cytokines, selectins, and tumor-associated macrophages. Instead of their normal function of phagocytosis of tumor cells, they promote cancer progression, matrix degradation, invasion and metastasis $[38,39]$. The use of anti-inflammatory drugs has been shown to significantly reduce the colorectal reoccurrence in patients with previous history of colorectal cancer [40]. The role of nonsteroidal anti-inflammatory drugs (NSAID) is well documented in lowering cancer incidence [41-43]. The mechanism of action of NSAIDs on inflammation is through the inactivation of cyclooxygenase-2 (COX-2), a key enzyme for the prostaglandin production

Table 1 Effects of phytoestrogen treatment on the cell cycle.

\begin{tabular}{|c|c|c|c|c|}
\hline $\begin{array}{l}\text { Nature of } \\
\text { isoflavone }\end{array}$ & Concentration & Cell type & Biological change & Reference \\
\hline $\begin{array}{l}\text { Genistein, glycitein, } \\
\text { and daidzein }\end{array}$ & $0,10,25$, and $50 \mu \mathrm{M}$ each & $\begin{array}{l}\text { human bladder cancer } \\
\text { cell line 253JB-V }\end{array}$ & $\begin{array}{l}\text { a) genistein, compared to other isoflavones, } \\
\text { significantly inhibited the cell growth } \\
\text { b) cell cycle arrest at G2/M transition }\end{array}$ & $\begin{array}{l}\text { Singh et al. } \\
2006[33]\end{array}$ \\
\hline Genistein & 2.5 to $40 \mu \mathrm{M}$ & $\begin{array}{l}\text { cervical cancer cell lines } \\
\text { CaSki and ME180 }\end{array}$ & $\begin{array}{l}\text { a) dose-dependent inhibition of both cell lines } \\
\text { b) cell cycle arrest at G2/M transition in ME180 } \\
\text { cell line only }\end{array}$ & $\begin{array}{l}\text { Yashar et al. } \\
2005[34]\end{array}$ \\
\hline $\begin{array}{l}\text { Genistein alone } \\
\text { or combined with } \\
\text { radiation }\end{array}$ & $\begin{array}{l}15 \mu \mathrm{M} \text { genistein alone or } \\
3 \text { Gy radiation alone or } 15 \mu \mathrm{M} \\
\text { genistein }+3 \text { Gy radiation }\end{array}$ & $\begin{array}{l}\text { prostate cancer cell line } \\
\text { PC-3 } \\
\text { human breast cancer cell } \\
\text { line BR231 } \\
\text { human renal cancer cell } \\
\text { lines } \mathrm{KCl}-18 \text { and RC-2 }\end{array}$ & $\begin{array}{l}\text { genistein combined with radiation compared } \\
\text { to either treatment alone } \\
\text { a) significantly inhibited cell growth in all cell } \\
\text { lines } \\
\text { b) significantly greater G2/M cell cycle arrest } \\
\text { c) downregulation of cyclin B1 } \\
\text { d) upregulation of P } 21 \text { WAF1 } \\
\text { pretreatment of cells with } 30 \mu M \text { genistein } \\
\text { followed by } 3 \text { Gy radiation significantly } \\
\text { decreased NF-kB DNA binding }\end{array}$ & $\begin{array}{l}\text { Raffoul et al. } \\
2006[35]\end{array}$ \\
\hline Genistein & 0 to $370 \mu \mathrm{M}$ & $\begin{array}{l}\text { human renal carcinoma } \\
\text { cell lines SMKT R-1, R-2, } \\
\text { R-3, and R-4 }\end{array}$ & $\begin{array}{l}\text { dose-dependent inhibition of growth and the } \\
100 \mu \mathrm{g} / \mathrm{L}(370 \mu \mathrm{M}) \text { dose resulted in a time- } \\
\text { dependent inhibition in all four cell lines }\end{array}$ & $\begin{array}{l}\text { Sasamura et al. } \\
2002[36]\end{array}$ \\
\hline
\end{tabular}


that plays an important role in inflammation, but the risk of gastrointestinal bleeding remains the major side effect of such treatment. In a recent study, red clover extract showed an anti-inflammatory effect comparable to that of hydrocortisone treatment in an in vivo chicken egg chorioallantoic membrane assay (CAM) [44].

Topical treatment with genistein alone or with capsaicin (a bioactive compound from peppers) in Sprague-Dawley rats, pretreated with $100 \mu \mathrm{M}$ 12-O-tetradecanoylphorbol 13-acetate (TPA) to induce an inflammatory response, effectively inhibited COX-2 and all three mitogen-activated protein kinases - pJNK, pERK, and pp38 [44]. Similar effects of genistein alone or in combination with capsaicin were observed in MCF-7 breast cancer cells [45]. In another study C57BL/6 mice were fed either a soyfree control diet or $3 \mathrm{~g} / \mathrm{kg}$ soy diet (total aglycone content of $298 \mathrm{mg} / \mathrm{g}$ in the diet) for 4 weeks, and were then injected with either $0.2 \mu \mathrm{g} / \mathrm{kg}$ body weight lipopolysaccharide (endotoxin) or vehicle. The soy-fed group showed inhibition of the endotoxin by maintaining the glutathione levels [46]. The expression of inflammation-induced genes, metallothionein and manganese superoxide dismutase, were significantly lower in the soy-fed group ( $\odot$ Table 2 ). The study revealed the dose-dependent inhibitory effects of genistein on IL-6 secretion in human intestinal Caco-2 cells. In a recent study of a rat model of inflammatory bowel disease, trinitrobenzene sulfonic acid-induced colitis in Wistar rats, a $100 \mathrm{mg} / \mathrm{kg}$ body weight oral dose of genistein significantly inhibited myeloperoxidase and COX-2 [47]. More recently, a case control study of gastric cancer patients revealed that a genetic polymorphism of the anti-inflammatory IL-10 gene and low soy intake were associated with an increased risk of gastric cancer compared to no polymorphism and high soy intake [48].

In the rat models of inflammation, soy and soy isoflavone treatment have shown promising results of COX-2 inhibition, without any side effects. In a 16-week soymilk supplementation study among US postmenopausal women, there was a significant reduction in inflammatory markers [49]. Randomized placebocontrolled trials are needed to further evaluate the anti-inflammatory effects of various phytoestrogens.

\section{Role of Phytoestrogens in Angiogenesis}

\section{$\checkmark$}

Angiogenesis is the process by which new blood vessels are formed from the existing vasculature. It is essential for normal physiological processes such as growth and wound healing, and is crucial in tumor progression [50,51]. Vascular endothelial growth factor (VEGF) is a potent stimulator of angiogenesis. Antiangiogenic drugs aim to inhibit tumor vascularization. The soy isoflavones genistein, daidzein, orobol (3'-hydroxygenistein) and factor 2 (6,7,4'-trihydroxyisoflavone) (० Fig. 1 ) significantly inhibit angiogenesis in the CAM assay [52]. Densitometric evaluation of the blood vessel surfaces showed that, compared to negative controls, genistein and daidzein reduced angiogenesis by $75 \%$ and $48 \%$, respectively. A recent study demonstrated that the soy isoflavones daidzein and genistein, as well as red clover extract, exerted antiangiogenic effects comparable to that of thalidomide (a potent antiangiogenic) in the CAM assay [44]. Although the CAM assay and the corneal assay are highly sensi-

Table 2 Effects of phytoestrogen treatment in animal models of cancer.

\begin{tabular}{|c|c|c|c|c|}
\hline $\begin{array}{l}\text { Nature of } \\
\text { isoflavone }\end{array}$ & Amount & Animal model & Biological response & Reference \\
\hline $\begin{array}{l}\text { Genistein or } \\
\text { genistein with } \\
\text { capsaicin }\end{array}$ & $\begin{array}{l}\text { topical treatment with } 25 \mu \mathrm{M} \\
\text { genistein or capsaicin alone or combined } \\
\text { in the rats, and } 50 \mu \mathrm{M} \text { each alone or to- } \\
\text { gether in the cell culture }\end{array}$ & $\begin{array}{l}\text { Sprague-Dawley rats } \\
\text { treated with } 100 \text { nM TPA } \\
\text { MCF-7 breast cancer cells } \\
\text { treated with } 20 \text { nM TPA }\end{array}$ & $\begin{array}{l}\text { inhibition of COX-2, pJNK, pERK, and } \\
\text { pp38 }\end{array}$ & $\begin{array}{l}\text { Hwang et al. } \\
2009 \text { [45] }\end{array}$ \\
\hline Novasoy diet & diet supplemented with $0.3 \%$ Novasoy & $\begin{array}{l}\text { male C57BL/ } 6 \text { mice fed } \\
\text { the experimental diet } \\
\text { followed with } 0.2 \mu \mathrm{g} / \mathrm{kg} \\
\text { body weight endotoxin } \\
\text { injection }\end{array}$ & $\begin{array}{l}\text { Novasoy treatment resulted in inhibition } \\
\text { of the endotoxin. }\end{array}$ & $\begin{array}{l}\text { Paradkar et al. } \\
2004[46]\end{array}$ \\
\hline Genistein & $\begin{array}{l}100 \mathrm{mg}(370 \mu \mathrm{mol}) / \mathrm{kg} \text { body weight } \\
\text { administered orally }\end{array}$ & $\begin{array}{l}\text { TNBS-induced chronic } \\
\text { colitis in Wistar rats }\end{array}$ & $\begin{array}{l}\text { significant reduction in } \mathrm{COX}-2 \text { and } \\
\text { myeloperoxidase }\end{array}$ & $\begin{array}{l}\text { Seibel et al. } \\
2009 \text { [47] }\end{array}$ \\
\hline Genistein & $\begin{array}{l}\text { human renal carcinoma cells }(\mathrm{RCC}) \\
\text { pretreated with } 100 \mu \mathrm{g} / \mathrm{mL}(370 \mu \mathrm{M}) \\
\text { genistein for } 12 \mathrm{~h} \text { or genistein } 100 \mu \mathrm{g} / \mathrm{mL} \\
(370 \mu \mathrm{M}) \text { put in Millipore filter chamber } \\
\text { with or without genistein pretreated RCC }\end{array}$ & $\begin{array}{l}\text { C57BL/6 mice with } \\
\text { human renal carcinoma } \\
\text { cells injected in dorsal air } \\
\text { sac }\end{array}$ & $\begin{array}{l}\text { No effect of genistein pretreatment } \\
\text { on vascular volume. } \\
\text { Genistein in Millipore without genistein } \\
\text { pretreated RCC decreased vascular } \\
\text { volume by } 48.9 \% \text {. } \\
\text { Genistein in Millipore with genistein } \\
\text { pretreated RCC decreased vascular } \\
\text { volume by } 56.4 \% \text {. }\end{array}$ & $\begin{array}{l}\text { Sasamura et al. } \\
2004[53]\end{array}$ \\
\hline \multirow[t]{2}{*}{$\begin{array}{l}\text { Genistein or } \\
\text { soybean-based diet }\end{array}$} & in vitro $1-100 \mu \mathrm{M}$ genistein & $\begin{array}{l}\text { in vitro B16F0 melanoma } \\
\text { F3II mammary carcinoma } \\
\text { cell lines }\end{array}$ & $\begin{array}{l}\text { no cytotoxicity with } 100 \mu \mathrm{M} \text { in both cell } \\
\text { lines }\end{array}$ & $\begin{array}{l}\text { Farina et al. } \\
2006[54]\end{array}$ \\
\hline & $\begin{array}{l}\text { in vivo } 15 \mathrm{mg}(55.5 \mu \mathrm{mol}) / \mathrm{kg} \text { body } \\
\text { weight genistein injection or soybean- } \\
\text { based diet }\end{array}$ & $\begin{array}{l}\text { in vivo Balb/c and } \mathrm{C} 57 \mathrm{BL} / 6 \\
\text { mice injected with } \mathrm{B} 16 \text { or } \\
\text { F3II cells }\end{array}$ & $\begin{array}{l}\text { 1-50 } \mu \mathrm{M} \text {, and } 20-50 \mu \mathrm{M} \text { genistein } \\
\text { significantly reduced tumor cell migra- } \\
\text { tion in F3II and B16F0 cells, respectively. } \\
\text { Both treatments reduced angiogenesis } \\
\text { in mice. }\end{array}$ & \\
\hline $\begin{array}{l}\text { Isoflavone mixture or } \\
\text { genistein followed } \\
\text { with } 5 \text { Gy photon } \\
\text { radiation }\end{array}$ & $\begin{array}{l}50 \mathrm{mg} / \mathrm{kg} \text { body weight isoflavone } \\
\text { mixture } \\
21.5 \mathrm{mg}(80 \mu \mathrm{mol}) / \mathrm{kg} \text { body weight } \\
\text { genistein }\end{array}$ & $\begin{array}{l}\text { male nu/nu mice with } \\
\text { established prostate } \\
\text { tumors with PC-3 cells } \\
\text { implants }\end{array}$ & $\begin{array}{l}\text { Isoflavone mixture with radiation } \\
\text { inhibited } 86 \% \text { of prostate tumor growth. } \\
\text { This inhibition was similar to that of } \\
\text { genistein followed by radiation. }\end{array}$ & $\begin{array}{l}\text { Raffoul et al. } \\
2007[61]\end{array}$ \\
\hline
\end{tabular}


tive assays to detect new vasculature, there is a large difference between these assays and an actual tumor environment. To address this issue, Sasamura et al. conducted a study with renal cell carcinoma cells injected in the female C57BL6 mice dorsal air sac, and treated them in situ with $100 \mu \mathrm{g} / \mathrm{mL}(370 \mu \mathrm{M})$ genistein which caused a $50 \%$ reduction in new vasculature compared with the vehicle [53]. As noted by the authors, this interesting result would have greater importance if genistein was antiangiogenic when using much lower concentrations $(1-10 \mu \mathrm{M})$, consistent with therapeutic doses.

Hormone-independent mammary tumor cells (F3II) and melanoma cells (B16F0) treated with a very high concentration $(100 \mu \mathrm{M})$ of genistein showed no cytotoxicity, and a lower concentration (1-50 $\mu \mathrm{M}$ in F3II cells and 20-50 $\mu \mathrm{M}$ in B16F0 cells) showed a significant reduction in tumor cell migration. The tumor cells were injected intradermally in C57BL/6 and BALB/C mice, which were treated either with a soy-based diet or a daily dose of $15 \mathrm{mg}$ $(55.6 \mu \mathrm{mol}) / \mathrm{kg}$ body weight genistein. Both treatments significantly reduced the new vasculature as compared to the control group [54]. In human breast cancer xenografted BALB/c nu/nu mice, treatment with a phytoestrogen supplemented diet as $10 \%$ ground flaxseed, or injected with the lignans enterodiol and enterolactone with $15 \mathrm{mg}(50 \mu \mathrm{mol}) / \mathrm{kg}$ body weight showed a significant decrease in tumor growth, extracellular VEGF, and tumor vasculature as compared with controls [55].

Phytoestrogens exert antiangiogenic effects through the inhibition of VEGF. Since the antiangiogenic effect of genistein is stronger as compared to other isoflavones, it is not known whether or not other phytoestrogens will have the similar effects on angiogenesis and if their mode of action will be through VEGF or some other mechanism.

\section{Role of Phytoestrogens in Reducing Metastases}

Metastasis is a multistep process by which tumor cells detach from the growing tumor mass, and migrate to form secondary tumors in distant tissues and organs of the body [56]. A large proportion of cancer mortality is due to deaths from metastases rather than from primary tumors. Phytoestrogens have shown promising results in this area of cancer therapy. Hydroxymatairesinol (HMR), a plant lignan and its metabolite enterolactone (ELN), a mammalian lignan, inhibit cell proliferation and invasion in rat hepatoma cells (AH109A) at $\geq 50 \mu \mathrm{M}$ and $>200 \mu \mathrm{M}$, respectively. A similar significant inhibitory effect was observed with serum from rats fed HMR [15 mg $(40 \mu \mathrm{mol}) / 100 \mathrm{~g}$ body weight] in an AH109A cell culture [57]. Many studies have reported the benefit of phytoestrogens to enhance the efficacy of cancer chemotherapeutics. A 10 -week treatment with either soy phytochemical concentrate or genistin (the $\beta$-glucoside form of genistein present in soy) in SCID mice xenografted with human bladder tumor cells showed a significant $52 \%$ and 54\% tumor reduction, respectively. Both treatments significantly reduced lung metastasis; however, no effect was observed for lymph node metastasis [33]. BALB/c mice transplanted with undifferentiated human pancreatic carcinoma cells with great metastatic potential (MIA PaCa-2) and treated with a daily $1.3 \mathrm{mg}$ intraperitoneal dose of genistein significantly inhibited distant metastasis, and improved survival as compared to the controls [58]. In a bone metastatic prostate cancer mouse (SCID) model, where mice were injected with the human PC3 cancer cells, a combined treatment of genistein with the chemotherapeutic docetaxel showed significant inhibition of tumor growth, downregulation of MMP9, and significant inhibition in invasion, compared to monotherapy with either compound alone [59]. In a postsurgical orthotopic breast cancer model where mammary fat pads of nude mice were injected with human ductal carcinoma cells (MDA-MD-435/HAL) with high lung metastatic potential, genistein treatment $[750 \mu \mathrm{g} / \mathrm{g}$ of diet - an approximate daily dose of $45 \mathrm{mg}(180 \mu \mathrm{mol}) / \mathrm{kg}$ body weight] for 70 days resulted in a significant inhibition in lung metastasis. Adjuvant treatment with genistein along with primary tumor resection using the above cancer model revealed a 100 -fold reduction in metastatic burden [60]. In both experiments genistein treatment significantly reduced cell proliferation and increased apoptosis within the lung metastasis.

Two studies where orthotopic prostate cancer bearing mice showed spontaneous metastasis to the lymph nodes upon treatment with genistein [oral dose of $5 \mathrm{mg}(18.5 \mu \mathrm{mol}) /$ day] alone as compared to genistein combined with radiation (5 Gy photons as single dose) have raised the question about its safety $[61,62]$. However, the median survival was similar in control and genistein-treated mice, and genistein treatment had no detrimental effects on survival. Nonetheless, genistein combined with radiation exerted a significant increase in survival which was greater than that of radiation alone. Genistein treatment was initiated 13 and 14 days post-tumor cell implantation, and there may be little or no effect when metastasis may have already started. Moreover, the sample size was fairly small (6-7 mice), and the lymph node weight was reported only in the short treatment group, with no data reported from the long-term genistein treatment group [62]. The investigators repeated the experiment and treated the same tumor model with $1 \mathrm{mg}$ /day soy isoflavone mixture (genistein, daidzein, and glycitein) or a lower dose of pure genistein $0.43 \mathrm{mg}(1.6 \mu \mathrm{mol}) /$ day, after the tumor xenograft was established. The treatment with a soy isoflavone mixture alone had no stimulatory effect on the lymph node weight, and there was no significant effect for genistein alone. Genistein or a soy isoflavone mixture as a combined therapy with radiation significantly inhibited metastasis [61]. Similarly, in a study of a human prostate cancer mouse BALB/c model, treatment with either $100 \mathrm{mg}(370 \mu \mathrm{mol})$ or $250 \mathrm{mg}(926 \mu \mathrm{mol}) / \mathrm{kg}$ of diet of genistein started prior to the cancer xenograft showed a significant reduction in lung metastasis, and no difference was observed for lymph node weight compared to control [63]. HMR treatment $(0.15 \%$ of diet) for 14 days in Donryu rats (4 weeks of age) bearing hepatoma resulted in significantly lower tumor weights and smaller tumors, and the rats had no metastasis. Similar effects of ELN treatment $(0.001 \%$ and $0.01 \%)$ were observed on tumor weights and metastasis [57].

There are several ongoing phase I, II, and III clinical trials on phytoestrogens as adjuvant therapy in cancer patients undergoing surgery, radiation, or hormonal manipulations for evaluation of the safety, and effectiveness ( Table 3) [64].

In summary, phytoestrogens in animal models of breast, prostate, bladder, and pancreatic cancer have shown significant inhibition of distant metastases. Phytoestrogen therapy along with primary treatment either with docetaxel or tumor resection showed significant improvement in metastasis inhibition. The animal data are encouraging, and phase I and II clinical trials are ongoing in this area. 


\section{Phytoestrogens Enhance the Efficacy of Cancer Therapy}

$\nabla$

Overcoming drug resistance is one of the challenges for anticancer therapies, as with time cancers develop resistance to chemotherapeutics, which is in part due to the activation of nuclear factor kappa B (NFKB). Many antitumor drugs act as stimulators for NFKB activation and DNA binding that is responsible for the drug resistance [65]. NFKB plays an important role in cell survival by protecting cells from apoptosis. Prostate cancer cells (PC-3) treated with a low-dose $3 \mathrm{~Gy}$ photon radiation exhibited significantly increased NFKB-DNA binding. However, pretreatment with a $30 \mu \mathrm{M}$ genistein dose for 24 hours prior to the irradiation significantly reduced the NFkB-DNA binding by 66\% [35]. Genistein treatment in a number of cancer cell lines including prostate, breast, renal cell carcinoma, as an adjuvant therapy followed by radiation, showed a greater effect than either therapy alone. Pretreatment with $15-30 \mu \mathrm{M}$ genistein in prostate, breast, lung, and pancreatic cancer cell lines significantly inhibits NFKB DNA binding and enhances the action of antitumor drugs by greater inhibition of cell proliferation and induction of apoptosis [66]. Genistein regulates the Akt signaling pathway [66]. Akt plays a critical role in cell survival and apoptosis, and regulates the NFKB pathway [67], suggesting dual role of genistein on NFKB.

In a metastatic prostate cancer model, PC-3 cancer cells implanted in the prostate of male nude mice, isoflavone therapy (50 mg/kg body weight/day) or an equivalent genistein dose [(0.43 mg $(1.6 \mu \mathrm{mol}) /$ day $)]$ along with radiation significantly inhibited prostate tumor growth compared with control, or either therapy alone. Although isoflavone treatment alone significantly inhibited the tumor growth [61], another study utilized the prostate cancer orthotopic model and demonstrated that a 4-week treatment with $5 \mathrm{mg}$ /day genistein given in combination with $5 \mathrm{~Gy}$ photon radiation resulted in a greater magnitude of tumor inhibition, and a significant increase in survival than either ther- apy administered alone [62]. In contrast, a high $5 \mathrm{mg}(18.5 \mu \mathrm{mol})$ / day dose of genistein to treat orthotopic renal cell carcinoma in nude mice resulted in a nonsignificant increase in tumor weight, and showed no effect to radiation at a dose of $8 \mathrm{~Gy}$. However, when radiation and genistein were given together, there was a significant inhibition of kidney tumor growth compared to control or either therapy alone [68]. Nonetheless, the Shanghai Breast Cancer Study reported an adverse outcome with radiotherapy compared to no radiotherapy in a population known to consume high amounts of soy food. However, the results may be skewed by the fact that radiation therapy was given to the most advanced staged breast cancer patients and no data were reported on dose and frequency of radiation [69].

In summary, phytoestrogens play an important role in NFKB regulation. Animal studies support the benefit of a combined regimen in cancer therapy as compared to radiation alone on tumor growth. Randomized clinical studies are needed to evaluate the extent of their chemotherapeutic potential in cancer patients.

\section{Randomized Clinical Trials of Phytoestrogens in Cancer Patients}

High phytoestrogen intake is well documented among Asian women, and the epidemiological evidence for the long-term intake of such compounds has shown them to be both safe and protective against many diseases including cancer. There has been an open question whether or not phytoestrogens are safe to be used among cancer patients [70,71]. Little is known about phytoestrogen intake among cancer patients. A recent cross-sectional study of 100 women treated for breast cancer at the Cancer Treatment Centers of America reported that $65 \%$ of patients have had some soy food with the mean daily intake of $11.6 \mathrm{mg}$ ( $43 \mu \mathrm{mol}$ ) genistein and $7.4 \mathrm{mg}(29 \mu \mathrm{mol})$ daidzein. The isoflavone dose is equivalent to a daily intake of $1 / 4$ cup of tofu, and is higher than the usual intake of isoflavones among non-Asian women [72], and the

Table 3 Ongoing clinical trials of phytoestrogens in cancer patients.

\begin{tabular}{|c|c|c|c|c|}
\hline Currently ongoing Study & Phase & Condition & Intervention & $\begin{array}{l}\text { ClinicalTrials.gov } \\
\text { identifier }\end{array}$ \\
\hline $\begin{array}{l}\text { Flaxseed and/or anastrozole in } \\
\text { treating postmenopausal women } \\
\text { undergoing surgery for newly } \\
\text { diagnosed stage I or II breast cancer }\end{array}$ & pilot study & $\begin{array}{l}\text { newly diagnosed primary, invasive breast cancer } \\
\text { estrogen receptor-positive tumor }\end{array}$ & $\begin{array}{l}\text { flaxseed, anastrozole, } \\
\text { or placebo }\end{array}$ & NCT00635908 \\
\hline $\begin{array}{l}\text { Genistein in treating patients } \\
\text { undergoing external-beam radia- } \\
\text { tion therapy for bone metastases }\end{array}$ & $\begin{array}{l}\text { phase I; } \\
\text { phase II }\end{array}$ & $\begin{array}{l}\text { histology confirmed malignant solid tumor, including } \\
\text { any of the following: breast cancer, kidney cancer, lung } \\
\text { cancer, prostate cancer, or melanoma }\end{array}$ & $\begin{array}{l}\text { genistein, radiation } \\
\text { therapy, and quality } \\
\text { of life assessment }\end{array}$ & NCT00769990 \\
\hline $\begin{array}{l}\text { Vitamin D and soy supplements in } \\
\text { treating patients with recurrent } \\
\text { prostate cancer }\end{array}$ & phase II & histology confirmed adenocarcinoma of the prostate & $\begin{array}{l}\text { cholecalciferol genis- } \\
\text { tein, and soy isofla- } \\
\text { vones }\end{array}$ & NCT00499408 \\
\hline $\begin{array}{l}\text { Genistein in treating patients with } \\
\text { pancreatic cancer that can be } \\
\text { removed by surgery }\end{array}$ & phase II & pancreatic adenocarcinoma & $\begin{array}{l}\text { genistein, and thera- } \\
\text { peutic conventional } \\
\text { surgery }\end{array}$ & NCT00882765 \\
\hline $\begin{array}{l}\text { Genistein in patients undergoing } \\
\text { surgery for bladder cancer }\end{array}$ & phase II & bladder cancer & $\begin{array}{l}\text { genistein versus } \\
\text { placebo }\end{array}$ & NCT00118040 \\
\hline $\begin{array}{l}\text { Clinical trial of purified isoflavones } \\
\text { in prostate cancer: comparing } \\
\text { safety and effectiveness }\end{array}$ & phase II & localized prostate cancer & purified isoflavones & NCT01036321 \\
\hline $\begin{array}{l}\text { Randomized study of soy protein/ } \\
\text { isoflavones and venlafaxine on va- } \\
\text { somotor symptoms in patints with } \\
\text { prostate cancer undergoing hor- } \\
\text { monal manipulations }\end{array}$ & phase III & histology confirmed prostate cancer & $\begin{array}{l}\text { soy protein/isofla- } \\
\text { vone powder, venla- } \\
\text { faxine, or placebo }\end{array}$ & NCT00354432 \\
\hline
\end{tabular}


lack of evidence on potential harm suggests that moderation may be the key to their use [73].

A study where 20 prostate cancer patients were treated with purified genistein [300 $\mathrm{mg}(1.11 \mathrm{mmol}) /$ day] for 28 days and with $600 \mathrm{mg}(2.22 \mathrm{mmol}) /$ day thereafter for another 56 days, showed no genotoxic effects, no changes in the micronuclei number and no chromosomal damage were observed when compared with pre-treatment status [74]. Recently, a randomized, double-blind, placebo study demonstrated no effect of a 12-week treatment with $20 \mathrm{~g}$ soy protein powder containing a high dose of phytoestrogens (160 mg total soy isoflavones) on cognition, sleep quality, sexual function and quality of life, in prostate cancer patients undergoing androgen deprivation therapy [75]. The investigators reported that soy protein or milk powder (placebo) was mixed in beverages. However, no data were reported on dietary intake; it is not known whether or not the subjects in both arms had any soy isoflavone intake through diet or supplementation prior to or during the study. The small sample size (16 subjects in the placebo, and 17 in the intervention arm) and absence of any measures of isoflavone and their metabolite levels in body fluids (urine or blood) makes it difficult to interpret the results. However, the high dose was well tolerated and there were no reports of any adverse effects from the intervention among prostate cancer patients. Similarly, no detrimental effects of soy powder treatment were observed in a pilot study with 18 prostate cancer patients receiving a two-step intervention to reduce fat intake to less than $15 \%$ of daily calories, followed by soy powder supplementation. In the median follow-up time of 10.5 (range 3-45) months, only 2 subjects successfully attained the fat calorie reduction of the study goals; also, the length of the soy supplementation was not clear, whether or not it was carried throughout the follow-up time. There was no information on the wide follow-up range of 3 months to 45 months, and no information on how many subjects were followed-up for short- or long-term periods [76]. In another study, 100 patients with isolated high-grade prostatic intraepithelial neoplasia were supplemented with a $100 \mathrm{mg}$ soy isoflavones along with $200 \mu \mathrm{g}$ selenium and $60 \mathrm{mg}$ vitamin $\mathrm{E}$ for 6 months. Two subgroups in the study population were identified; the larger group (68\% of subjects) with a significant decrease in prostate specific antigen (PSA) levels from baseline, and only $16 \%$ men with diagnosed prostate cancer. A small proportion of subjects had elevated PSA levels after the intervention, and $25 \%$ of the men in this group were diagnosed with the cancer. However, in the absence of a control group, it is not clear whether the PSA levels changed due to the phytoestrogens or the underlying disease progression over time [77]. A phase II, randomized, placebo-controlled trial of $80 \mathrm{mg} /$ day isoflavone treatment among localized prostate cancer patients for 12 weeks did not find any significant effects on serum hormone binding globulin, total estradiol, or testosterone $[78,79]$. Nonetheless, the isoflavone dose resulted in a significant increase in serum isoflavone levels among the intervention arm without any cytotoxicity or harmful effects $[78,79]$.

A randomized, placebo-controlled, double-blind study of flaxseed supplementation for a month in postmenopausal breast cancer patients showed a significant reduction in tumor cell proliferation, c-erb B2 expression, and increased apoptosis [80]. The study used whole wheat flour for the placebo group, which is known to have a high lignan content $[23,24]$. The effect size may have been stronger if the placebo were a true placebo (no lignans). In a crossover design 7 postmenopausal breast cancer survivors were given supplementation with $138 \mathrm{mg}$ soy isoflavones per day for 24 days, and following a two-week washout period, the subjects were crossed over to the placebo group. The subjects were blinded to the intervention and the order of the treatment was random. Changes in the superoxide dismutase (SOD1) enzyme were measured as a surrogate marker of antioxidant activity of isoflavones. The treatment significantly increased erythrocyte SOD1, and the increased levels were associated with a lower risk for breast cancer recurrence [81] ( 0 Table 4).

\section{Role of Phytoestrogens on Survival}

$\nabla$

In transgenic mice with prostatic adenocarcinoma, genistein treatment at a dose of $250(0.93 \mathrm{mmol})$ or $500 \mathrm{mg}(1.85 \mathrm{mmol})$ / $\mathrm{kg}$ diet for 28 weeks inhibited poorly differentiated cancer, improved survival, and significantly reduced osteopontin (OPN, extracellular matrix protein secreted by the macrophages) compared to the mice fed a genistein-free diet $[82,83]$. Similarly, genistein given as a preventive treatment (in mice 4-20 weeks of age) prior to tumor initiation reduced OPN dose-dependently, but when genistein treatment was started on 12-week-old mice, a lower concentration increased OPN levels [84]. The elevated level of OPN is associated with tumor progression and increased metastatic potential. A recent study of targeting OPN by anti-OPN antibody in nude mice bearing highly metastatic breast cancer demonstrated the increased tumor latency and inhibited lung metastases [85]. There is an inverse relation between OPN levels and survival among prostate cancer patients [86].

Only a little is known about the effect of phytoestrogens on cancer survival in patients. We were able to locate three studies of such a nature. The first study was conducted among women from Long Island, California, USA; all-cause mortality significantly decreased for subjects in the highest vs. lowest quintile of isoflavone intake among both postmenopausal and premenopausal women. There was a modest reduction in breast cancer mortality [87]. The other was the follow-up study from the Shanghai breast cancer cohort study where the total soy food intake was analyzed as soy protein or isoflavones, and showed no association with breast cancer survival. However, there were no data on the type of chemotherapeutics used, and the distribution of tamoxifen use among the study population [69]. The null association at least assures no harm associated with the use of soy in breast cancer patients. However, more recently, the Shanghai breast survival study, a large population-based follow-up cohort of breast cancer survivors in China, showed that soy protein or isoflavone intake was significantly associated with decreases in cancer recurrence and mortality. The inverse association was observed regardless of estrogen receptor or tamoxifen users and menopausal status, suggesting their safe use among breast cancer patients [88]. This result is tempered by previous findings that adolescent exposure to soy (as tofu consumption) is conditional for the lowered adult risk of breast cancer $[89,90]$. Therefore, while benefits of soy with respect to lowered recurrence and prolonged survival occurred in these Chinese women, it cannot be assumed that this result will apply to groups who did not have early life exposure to soy and its isoflavones. 


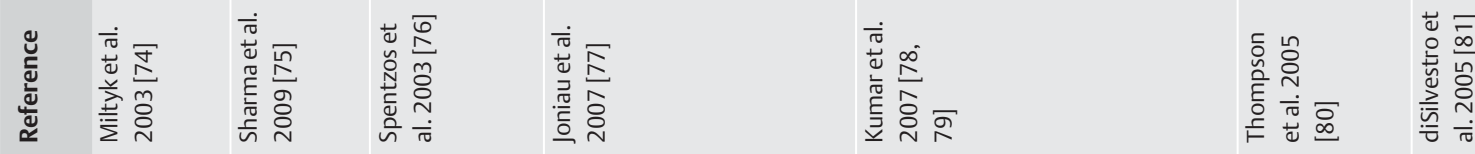

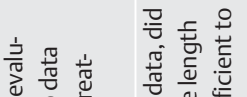

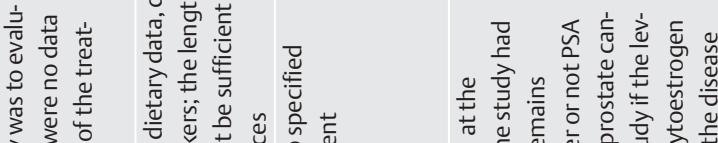

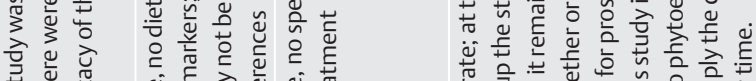

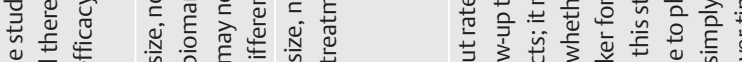

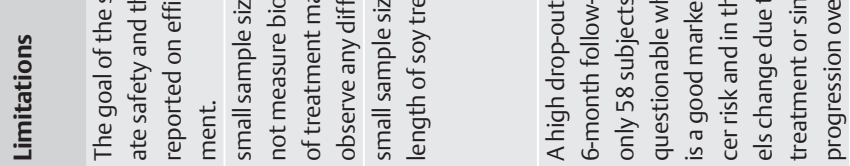

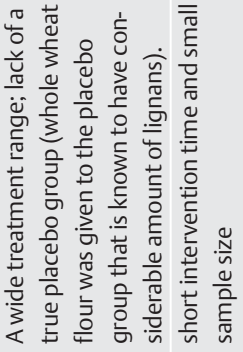

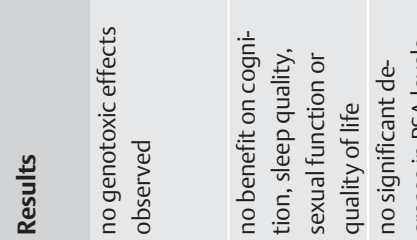

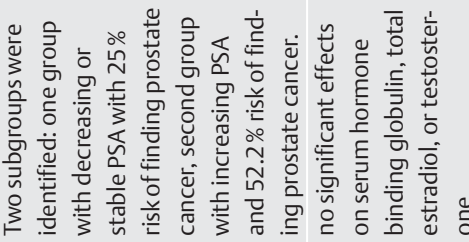

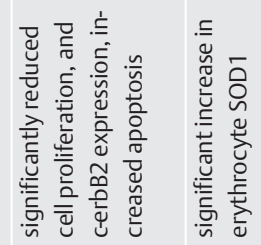
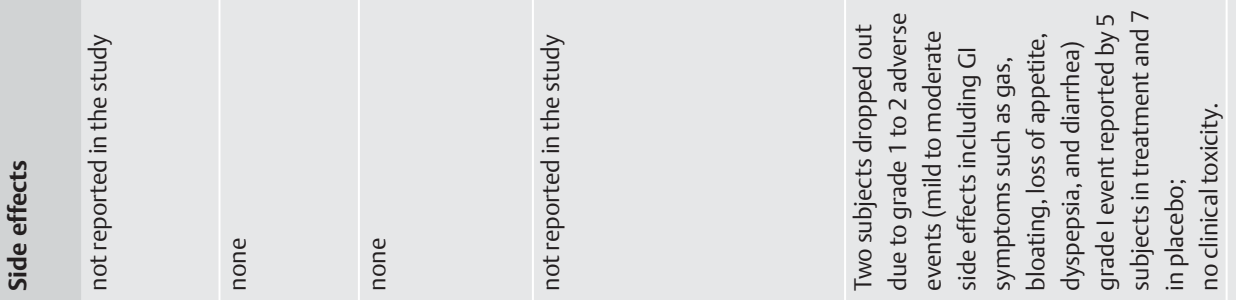

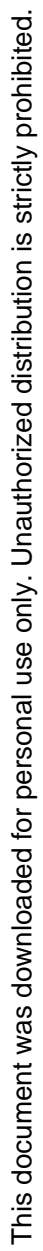

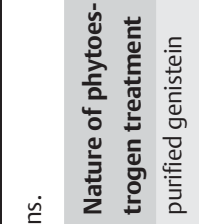

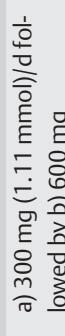

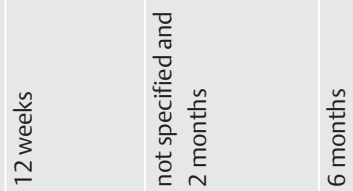

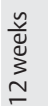

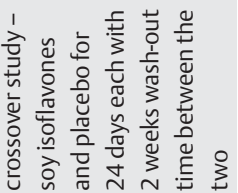

产

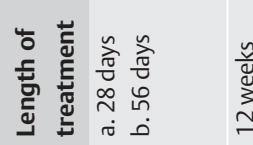

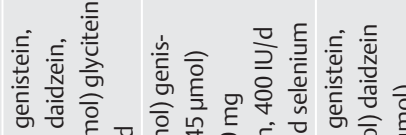

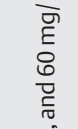

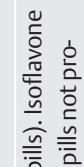

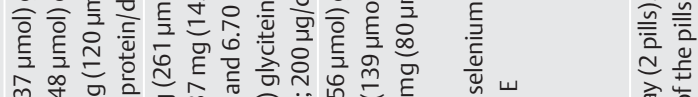

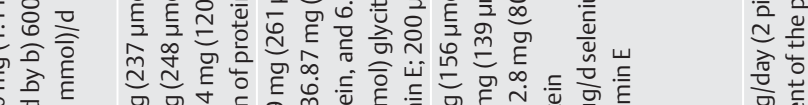

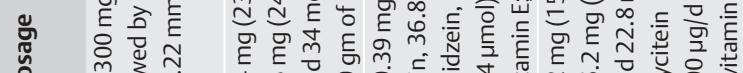

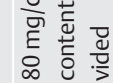

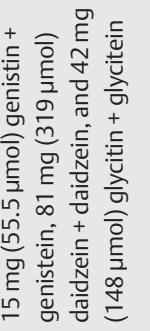

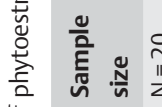

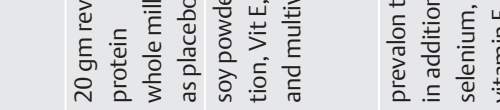
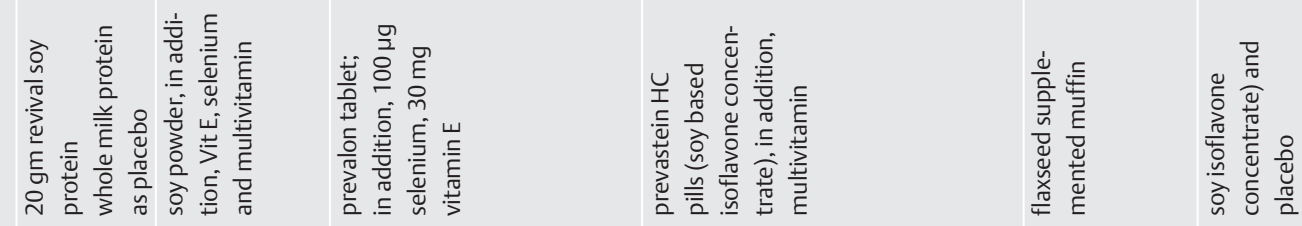

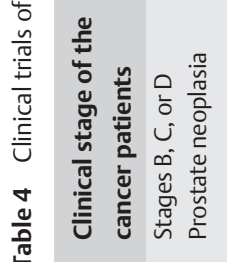

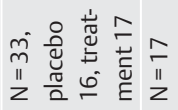

$\frac{8}{11}$

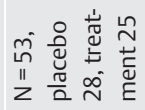

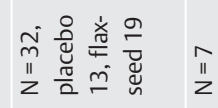

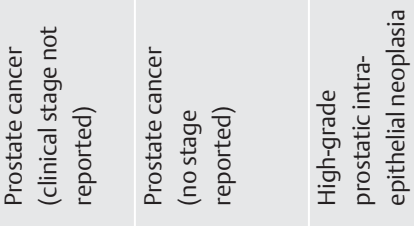

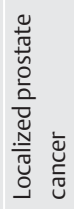

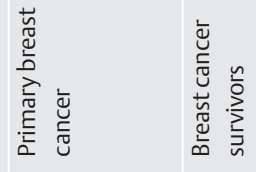




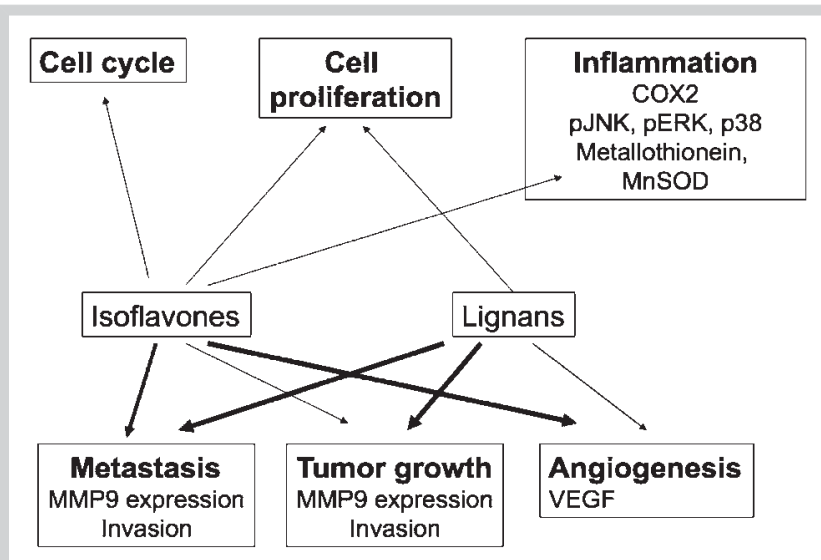

Fig. 3 Summary of the targets of phytoestrogens. The majority of the effects were identified in experiments using the isoflavone genistein. The lignans have qualitatively different effects to the isoflavones. The majority of the effects were negative in nature. However, genistein stimulates the proliferation of estrogen receptor-positive cells at low $(<1 \mu \mathrm{M})$ concentrations. The boldness of the arrows indicates the strength of the data as determined by this review.

\section{Conclusions}

$\nabla$

There is evidence for the role of phytoestrogens in cell cycle arrest, antiangiogenic potential, antimetastatic potential and in enhancing radiotherapy treatment. In the rodent cancer models phytoestrogens significantly inhibit tumor growth, invasion and metastasis ( Fig. 3). Phytoestrogens have shown to be beneficial in reducing the resistance to anticancer drugs through regulating NFKB. The objective measures of phytoestrogen intake compliance are lacking in most of the clinical trials and wide ranges (80-600 mg/day) of doses have been used among cancer patients. However, the lack of side effects at the highest dose [600 mg (2.22 mmol)/day] of pure genistein at least assures their safe use among this population. More recently, high phytoestrogen intake has been shown to reduce cancer recurrence and mortality among breast cancer survivors. However, the minimum effective dose and whether it is going to differ according to the stage and type of cancer are yet to be determined. The individual differences in metabolism may play another important role in determining the effective dose. It is not known whether these effects of phytoestrogens would vary by obesity status and degree of obeseness. The use of phytoestrogens in cancer therapy holds potential for further research.

\section{Acknowledgements \\ $\nabla$}

We would like to thank Maria Johnson, Xingsheng Li, and Daniel Smith for their help with the proofreading of this manuscript. Research on phytoestrogens and cancer is funded in part by grants from the National Cancer Institute (U54 CA100949 and R21 AT04661, S. Barnes, PI). M. Virk-Baker and T. Nagy are supported in part by the Cancer Prevention and Control Training Program (R25 CA047888). The opinions expressed herein are those of the authors and not necessarily those of the NIH or any other organization with which the authors are affiliated.

\section{References}

1 Russo IH, Russo J. Role of hormones in mammary cancer initiation and progression. J Mammary Gland Biol Neoplasia 1998; 3: 49-61

2 Huggins CHC. Studies on prostatic cancer. I. The effect of castration, of estrogen and of androgen injection on serum phosphatases in metastatic carcinoma of the prostate. Cancer Res 1941; 1: 293-297

3 Fritsch M, Jordan VC. Long-term tamoxifen therapy for the treatment of breast cancer. Cancer Control 1994; 1: 356-366

4 Miller WR. Aromatase inhibitors: mechanism of action and role in the treatment of breast cancer. Semin Oncol 2003; 30 (4 Suppl. 14): 3-11

5 Lieberman $R$. Androgen deprivation therapy for prostate cancer chemoprevention: current status and future directions for agent development. Urology 2001; 58 (2 Suppl. 1): 83-90

6 Lobo RA. Benefits and risks of estrogen replacement therapy. Am J Obstet Gynecol 1995; 173: 982-989

7 Rossouw JE, Anderson GL, Prentice RL, LaCroix AZ, Kooperberg C, Stefanick ML, Jackson RD, Beresford SA, Howard BV, Johnson KC, Kotchen JM, Ockene J. Risks and benefits of estrogen plus progestin in healthy postmenopausal women: principal results from the women's health initiative randomized controlled trial. JAMA 2002; 288: 321-333

8 Pritchard KI. Breast cancer prevention with selective estrogen receptor modulators: a perspective. Ann NY Acad Sci 2001; 949: 89-98

9 Cummings SR, Eckert S, Krueger KA, Grady D, Powles TJ, Cauley JA, Norton L, Nickelsen T, Bjarnason NH, Morrow M, Lippman ME, Black D, Glusman JE, Costa A, Jordan VC. The effect of raloxifene on risk of breast cancer in postmenopausal women: results from the MORE randomized trial. Multiple outcomes of raloxifene evaluation. JAMA 1999; 281: 2189-2197

10 St Clair RW. Estrogens and atherosclerosis: phytoestrogens and selective estrogen receptor modulators. Curr Opin Lipidol 1998; 9: 457-463

11 Oseni T, Patel R, Pyle J, Jordan VC. Selective estrogen receptor modulators and phytoestrogens. Planta Med 2008; 74: 1656-1665

12 Akiyama T, Ishida J, Nakagawa S, Ogawara H, Watanabe S, Itoh N, Shibuya M, Fukami Y. Genistein, a specific inhibitor of tyrosine-specific protein kinases. J Biol Chem 1987; 262: 5592-5595

13 Barnes $S$. The biochemistry, chemistry and physiology of the isoflavones in soybeans and their food products. Lymphat Res Biol 2010; 8: 89-98

14 Davis JN, Kucuk O, Sarkar FH. Genistein inhibits NF-kappa B activation in prostate cancer cells. Nutr Cancer 1999; 35: 167-174

15 Krazeisen A, Breitling R, Moller G, Adamski J. Phytoestrogens inhibit human 17beta-hydroxysteroid dehydrogenase type 5. Mol Cell Endocrinol 2001; 171: 151-162

16 Rice S, Mason HD, Whitehead SA. Phytoestrogens and their low dose combinations inhibit mRNA expression and activity of aromatase in human granulosa-luteal cells. J Steroid Biochem Mol Biol 2006; 101: 216-225

17 Dang ZC, Audinot V, Papapoulos SE, Boutin JA, Lowik CW. Peroxisome proliferator-activated receptor gamma (PPARgamma) as a molecular target for the soy phytoestrogen genistein. J Biol Chem 2003; 278: 962-967

18 Chacko BK, Chandler RT, Mundhekar A, Khoo N, Pruitt HM, Kucik DF, Parks DA, Kevil CG, Barnes S, Patel RP. Revealing anti-inflammatory mechanisms of soy isoflavones by flow: modulation of leukocyte-endothelial cell interactions. Am J Physiol Heart Circ Physiol 2005; 289 : H908-H915

19 Wu AH, Ziegler RG, Horn-Ross PL, Nomura AM, West DW, Kolonel LN, Rosenthal JF, Hoover RN, Pike MC. Tofu and risk of breast cancer in Asian-Americans. Cancer Epidemiol Biomarkers Prev 1996; 5: 901906

20 Kurahashi N, Iwasaki M, Sasazuki S, Otani T, Inoue M, Tsugane S. Soy product and isoflavone consumption in relation to prostate cancer in Japanese men. Cancer Epidemiol Biomarkers Prev 2007; 16: 538-545

21 Busby MG, Jeffcoat AR, Bloedon LT, Koch MA, Black T, Dix KJ, Heizer WD, Thomas BF, Hill JM, Crowell JA, Zeisel SH. Clinical characteristics and pharmacokinetics of purified soy isoflavones: single-dose administration to healthy men. Am J Clin Nutr 2002; 75: 126-136

22 Bloedon LT, Jeffcoat AR, Lopaczynski W, Schell MJ, Black TM, Dix KJ, Thomas BF, Albright C, Busby MG, Crowell JA, Zeisel SH. Safety and pharmacokinetics of purified soy isoflavones: single-dose administration to postmenopausal women. Am J Clin Nutr 2002; 76: 1126-1137

23 Smeds AI, Eklund PC, Sjoholm RE, Willfor SM, Nishibe S, Deyama T, Holmbom BR. Quantification of a broad spectrum of lignans in cereals, oilseeds, and nuts. J Agric Food Chem 2007; 55: 1337-1346 
24 Smeds AI, Jauhiainen L, Tuomola E, Peltonen-Sainio P. Characterization of variation in the lignan content and composition of winter rye, spring wheat, and spring oat. J Agric Food Chem 2009; 57: 5837-5842

25 Clavel T, Dore J, Blaut M. Bioavailability of lignans in human subjects. Nutr Res Rev 2006; 19: 187-196

26 Duncan AM, Phipps WR, Kurzer MS. Phyto-oestrogens. Best Pract Res Clin Endocrinol Metab 2003; 17: 253-271

27 Wiseman $H$. The bioavailability of non-nutrient plant factors: dietary flavonoids and phyto-oestrogens. Proc Nutr Soc 1999; 58: 139-146

28 USDA Database for Isoflavone Content of Selected Foods. Release 2.0. Available at http://www.ars.usda.gov/Services/docs.htm?docid=6382. Accessed November 12, 2009

29 Sfakianos J, Coward L, Kirk M, Barnes S. Intestinal uptake and biliary excretion of the isoflavone genistein in rats. J Nutr 1997; 127: 1260-1268

30 Kano M, Takayanagi T, Harada K, Sawada S, Ishikawa F. Bioavailability of isoflavones after ingestion of soy beverages in healthy adults. J Nutr 2006; 136: 2291-2296

31 Hedlund TE, Maroni PD, Ferucci PG, Dayton R, Barnes S, Jones K, Moore R, Ogden LG, Wahala K, Sackett HM, Gray KJ. Long-term dietary habits affect soy isoflavone metabolism and accumulation in prostatic fluid in Caucasian men. J Nutr 2005; 135: 1400-1406

32 Sorrentino V. The cell cycle. In: Pusztai L, Lewis CE, Yap E, editors. Cell proliferation in cancer, regulatory mechanisms of neoplastic growth. Oxford: Oxford Medical Publications; 1995: 25-41

33 Singh AV, Franke AA, Blackburn GL, Zhou JR. Soy phytochemicals prevent orthotopic growth and metastasis of bladder cancer in mice by alterations of cancer cell proliferation and apoptosis and tumor angiogenesis. Cancer Res 2006; 66: 1851-1858

34 Yashar CM, Spanos WJ, Taylor DD, Gercel-Taylor C. Potentiation of the radiation effect with genistein in cervical cancer cells. Gynecol Oncol 2005; 99: 199-205

35 Raffoul JJ, Wang Y, Kucuk O, Forman JD, Sarkar FH, Hillman GG. Genistein inhibits radiation-induced activation of NF-kappaB in prostate cancer cells promoting apoptosis and G2/M cell cycle arrest. BMC Cancer 2006; 6: 107

36 Sasamura H, Takahashi A, Miyao N, Yanase M, Masumori N, Kitamura H, Itoh $\mathrm{N}$, Tsukamoto $\mathrm{T}$. Inhibitory effect on expression of angiogenic factors by antiangiogenic agents in renal cell carcinoma. Br J Cancer 2002; 86: 768-773

37 Darby IA, Hewitson TD. Fibroblast differentiation in wound healing and fibrosis. Int Rev Cytol 2007; 257: 143-179

38 Coussens LM, Werb Z. Inflammation and cancer. Nature 2002; 420: 860-867

39 Ditsworth D, Zong WX. NF-kappaB: key mediator of inflammation-associated cancer. Cancer Biol Ther 2004; 3: 1214-1216

40 Sandler RS, Halabi S, Baron JA, Budinger S, Paskett E, Keresztes R, Petrelli $N$, Pipas JM, Karp DD, Loprinzi CL, Steinbach G, Schilsky R. A randomized trial of aspirin to prevent colorectal adenomas in patients with previous colorectal cancer. N Engl J Med 2003; 348: 883-890

41 Chan AT, Giovannucci EL, Meyerhardt JA, Schernhammer ES, Curhan GC, Fuchs CS. Long-term use of aspirin and nonsteroidal anti-inflammatory drugs and risk of colorectal cancer. JAMA 2005; 294: 914-923

42 Chan AT. Aspirin, non-steroidal anti-inflammatory drugs and colorectal neoplasia: future challenges in chemoprevention. Cancer Causes Control 2003; 14: 413-418

43 Flossmann E, Rothwell PM. Effect of aspirin on long-term risk of colorectal cancer: consistent evidence from randomised and observational studies. Lancet 2007; 369: 1603-1613

44 Krenn L, Paper DH. Inhibition of angiogenesis and inflammation by an extract of red clover (Trifolium pratense L.). Phytomedicine 2009; 16: 1083-1088

45 Hwang JT, Lee YK, Shin JI, Park OJ. Anti-inflammatory and anticarcinogenic effect of genistein alone or in combination with capsaicin in TPAtreated rat mammary glands or mammary cancer cell line. Ann NY Acad Sci 2009; 1171: 415-420

46 Paradkar PN, Blum PS, Berhow MA, Baumann H, Kuo SM. Dietary isoflavones suppress endotoxin-induced inflammatory reaction in liver and intestine. Cancer Lett 2004; 215: 21-28

47 Seibel J, Molzberger AF, Hertrampf T, Laudenbach-Leschowski U, Diel P. Oral treatment with genistein reduces the expression of molecular and biochemical markers of inflammation in a rat model of chronic TNBS-induced colitis. Eur J Nutr 2009; 48: 213-220

48 Ko KP, Park SK, Cho LY, Gwack J, Yang JJ, Shin A, Kim CS, Kim Y, Kang D, Chang SH, Shin HR, Yoo KY. Soybean product intake modifies the associ- ation between interleukin-10 genetic polymorphisms and gastric cancer risk. J Nutr 2009; 139: 1008-1012

49 Huang Y, Cao S, Nagamani M, Anderson KE, Grady JJ, Lu LJ. Decreased circulating levels of tumor necrosis factor-alpha in postmenopausal women during consumption of soy-containing isoflavones. J Clin Endocrinol Metab 2005; 90: 3956-3962

50 Battegay EJ. Angiogenesis: mechanistic insights, neovascular diseases, and therapeutic prospects. J Mol Med 1995; 73: 333-346

51 Folkman J. Angiogenesis in cancer, vascular, rheumatoid and other disease. Nat Med 1995; 1: 27-31

52 Kiriakidis S, Hogemeier O, Starcke S, Dombrowski F, Hahne JC, Pepper M, Jha HC, Wernert N. Novel tempeh (fermented soyabean) isoflavones inhibit in vivo angiogenesis in the chicken chorioallantoic membrane assay. Br J Nutr 2005; 93: 317-323

53 Sasamura H, Takahashi A, Yuan J, Kitamura H, Masumori N, Miyao N, Itoh $\mathrm{N}$, Tsukamoto $\mathrm{T}$. Antiproliferative and antiangiogenic activities of genistein in human renal cell carcinoma. Urology 2004; 64: 389-393

54 Farina HG, Pomies M, Alonso DF, Gomez DE. Antitumor and antiangiogenic activity of soy isoflavone genistein in mouse models of melanoma and breast cancer. Oncol Rep 2006; 16: 885-891

55 Bergman JM, Thompson LU, Dabrosin C. Flaxseed and its lignans inhibit estradiol-induced growth, angiogenesis, and secretion of vascular endothelial growth factor in human breast cancer xenografts in vivo. Clin Cancer Res 2007; 13: 1061-1067

56 Fidler IJ. Cancer metastasis. Br Med Bull 1991; 47: 157-177

57 Miura D, Saarinen NM, Miura Y, Santti R, Yagasaki K. Hydroxymatairesinol and its mammalian metabolite enterolactone reduce the growth and metastasis of subcutaneous AH109A hepatomas in rats. Nutr Cancer 2007; 58: 49-59

58 Buchler P, Gukovskaya AS, Mouria M, Buchler MC, Buchler MW, Friess $H$ Pandol SJ, Reber HA, Hines OJ. Prevention of metastatic pancreatic cancer growth in vivo by induction of apoptosis with genistein, a naturally occurring isoflavonoid. Pancreas 2003; 26: 264-273

59 Li Y, Kucuk O, Hussain M, Abrams J, Cher ML, Sarkar FH. Antitumor and antimetastatic activities of docetaxel are enhanced by genistein through regulation of osteoprotegerin/receptor activator of nuclear factor-kappaB (RANK)/RANK ligand/MMP-9 signaling in prostate cancer. Cancer Res 2006; 66: 4816-4825

60 Vantyghem SA, Wilson SM, Postenka CO, Al-Katib W, Tuck AB, Chambers $A F$. Dietary genistein reduces metastasis in a postsurgical orthotopic breast cancer model. Cancer Res 2005; 65: 3396-3403

61 Raffoul IJ, Banerjee S, Che M, Knoll ZE, Doerge DR, Abrams J, Kucuk O, Sarkar FH, Hillman GG. Soy isoflavones enhance radiotherapy in a metastatic prostate cancer model. Int J Cancer 2007; 120: 2491-2498

62 Hillman GG, Wang Y, Kucuk O, Che M, Doerge DR, Yudelev M, Joiner MC, Marples B, Forman JD, Sarkar FH. Genistein potentiates inhibition of tumor growth by radiation in a prostate cancer orthotopic model. Mol Cancer Ther 2004; 3: 1271-1279

63 Lakshman M, Xu L, Ananthanarayanan V, Cooper J, Takimoto CH, Helenowski I, Pelling JC, Bergan RC. Dietary genistein inhibits metastasis of human prostate cancer in mice. Cancer Res 2008; 68: 2024-2032

64 ClinicalTrials.gov. http://www.clinicaltrials.gov. Accessed April 07, 2010

65 Chuang SE, Yeh PY, Lu YS, Lai GM, Liao CM, Gao M, Cheng AL. Basal levels and patterns of anticancer drug-induced activation of nuclear factorkappaB (NF-kappaB), and its attenuation by tamoxifen, dexamethasone, and curcumin in carcinoma cells. Biochem Pharmacol 2002; 63: 1709-1716

66 Li Y, Ahmed F, Ali S, Philip PA, Kucuk O, Sarkar FH. Inactivation of nuclear factor kappaB by soy isoflavone genistein contributes to increased apoptosis induced by chemotherapeutic agents in human cancer cells. Cancer Res 2005; 65: 6934-6942

67 Gustin JA, Ozes ON, Akca H, Pincheira R, Mayo LD, Li Q Guzman JR, Korgaonkar CK, Donner DB. Cell type-specific expression of the IkappaB kinases determines the significance of phosphatidylinositol 3-kinase/Akt signaling to NF-kappa B activation. J Biol Chem 2004; 279: 1615-1620

68 Hillman GG, Wang Y, Che M, Raffoul JJ, Yudelev M, Kucuk O, Sarkar FH. Progression of renal cell carcinoma is inhibited by genistein and radiation in an orthotopic model. BMC Cancer 2007; 7: 4

69 Boyapati SM, Shu XO, Ruan ZX, Dai Q Cai Q Gao YT, Zheng W. Soyfood intake and breast cancer survival: a followup of the Shanghai Breast Cancer Study. Breast Cancer Res Treat 2005; 92: 11-17

70 De LM. Safety issues of soy phytoestrogens in breast cancer patients. J Clin Oncol 2002; 20: 3040-3041 
71 Velentzis LS, Woodside JV, Cantwell MM, Leathem AJ, Keshtgar MR. Do phytoestrogens reduce the risk of breast cancer and breast cancer recurrence? What clinicians need to know. Eur J Cancer 2008; 44: 1799-1806

72 Lammersfeld CA, King J, Walker S, Vashi PG, Grutsch JF, Lis CG, Gupta D. Prevalence, sources, and predictors of soy consumption in breast cancer. Nutr J 2009; 8: 2

73 Messina MJ, Loprinzi CL. Soy for breast cancer survivors: a critical review of the literature. J Nutr 2001; 131: 3095S-3108S

74 Miltyk W, Craciunescu CN, Fischer L, Jeffcoat RA, Koch MA, Lopaczynski W, Mahoney C, Jeffcoat RA, Crowell J, Paglieri J, Zeisel SH. Lack of significant genotoxicity of purified soy isoflavones (genistein, daidzein, and glycitein) in 20 patients with prostate cancer. Am J Clin Nutr 2003; 77: 875-882

75 Sharma P, Wisniewski A, Braga-Basaria M, Xu X, Yep M, Denmeade S, Dobs AS, DeWeese T, Carducci M, Basaria S. Lack of an effect of high dose isoflavones in men with prostate cancer undergoing androgen deprivation therapy. J Urol 2009; 182: 2265-2272

76 Spentzos D, Mantzoros C, Regan MM, Morrissey ME, Duggan S, FlicknerGarvey S, McCormick H, DeWolf W, Balk S, Bubley GJ. Minimal effect of a low-fat/high soy diet for asymptomatic, hormonally naive prostate cancer patients. Clin Cancer Res 2003; 9: 3282-3287

77 Joniau S, Goeman L, Roskams T, Lerut E, Oyen R, Van PH. Effect of nutritional supplement challenge in patients with isolated high-grade prostatic intraepithelial neoplasia. Urology 2007; 69: 1102-1106

78 Kumar NB, Krischer JP, Allen K, Riccardi D, Besterman-Dahan K, Salup R, Kang $L, X u$ P, Pow-Sang J. A phase II randomized, placebo-controlled clinical trial of purified isoflavones in modulating steroid hormones in men diagnosed with localized prostate cancer. Nutr Cancer 2007; 59: $163-168$

79 Kumar NB, Krischer JP, Allen K, Riccardi D, Besterman-Dahan K, Salup R, Kang L, Xu P, Pow-Sang J. Safety of purified isoflavones in men with clinically localized prostate cancer. Nutr Cancer 2007; 59: 169-175

80 Thompson LU, Chen JM, Li T, Strasser-Weippl K, Goss PE. Dietary flaxseed alters tumor biological markers in postmenopausal breast cancer. Clin Cancer Res 2005; 11: 3828-3835
81 DiSilvestro RA, Goodman J, Dy E, Lavalle G. Soy isoflavone supplementation elevates erythrocyte superoxide dismutase, but not plasma ceruloplasmin in postmenopausal breast cancer survivors. Breast Cancer Res Treat 2005; 89: 251-255

82 Mentor-Marcel R, Lamartiniere CA, Eltoum IA, Greenberg NM, Elgavish A. Dietary genistein improves survival and reduces expression of osteopontin in the prostate of transgenic mice with prostatic adenocarcinoma (TRAMP). J Nutr 2005; 135: 989-995

83 Mentor-Marcel R, Lamartiniere CA, Eltoum IE, Greenberg NM, Elgavish A Genistein in the diet reduces the incidence of poorly differentiated prostatic adenocarcinoma in transgenic mice (TRAMP). Cancer Res 2001; 61: 6777-6782

84 El Touny LH, Banerjee PP. Identification of a biphasic role for genistein in the regulation of prostate cancer growth and metastasis. Cancer Res 2009; 69: 3695-3703

85 Dai J, Li B, Shi J, Peng L, Zhang D, Qian W, Hou S, Zhao L, Gao J, Cao Z, Zhao J, Wang H, Guo Y. A humanized anti-osteopontin antibody inhibits breast cancer growth and metastasis in vivo. Cancer Immunol Immunother 2010; 59: 355-366

86 Forootan SS, Foster CS, Aachi VR, Adamson J, Smith PH, Lin K, Ke Y. Prognostic significance of osteopontin expression in human prostate cancer. Int J Cancer 2006; 118: 2255-2261

87 Fink BN, Steck SE, Wolff MS, Britton JA, Kabat GC, Gaudet MM, Abrahamson PE, Bell P, Schroeder JC, Teitelbaum SL, Neugut AI, Gammon MD. Dietary flavonoid intake and breast cancer survival among women on Long Island. Cancer Epidemiol Biomarkers Prev 2007; 16: 2285-2292

88 Shu XO, Zheng Y, Cai H, Gu K, Chen Z, Zheng W, Lu W. Soy food intake and breast cancer survival. JAMA 2009; 302: 2437-2443

89 Korde LA, Wu AH, Fears T, Nomura AM, West DW, Kolonel LN, Pike MC, Hoover RN, Ziegler RG. Childhood soy intake and breast cancer risk in Asian American women. Cancer Epidemiol Biomarkers Prev 2009; 18: 1050-1059

90 Lee SA, Shu XO, Li H, Yang G, Cai H, Wen W, Ji BT, Gao J, Gao YT, Zheng W. Adolescent and adult soy food intake and breast cancer risk: results from the Shanghai Women's Health Study. Am J Clin Nutr 2009; 89: 1920-1926 